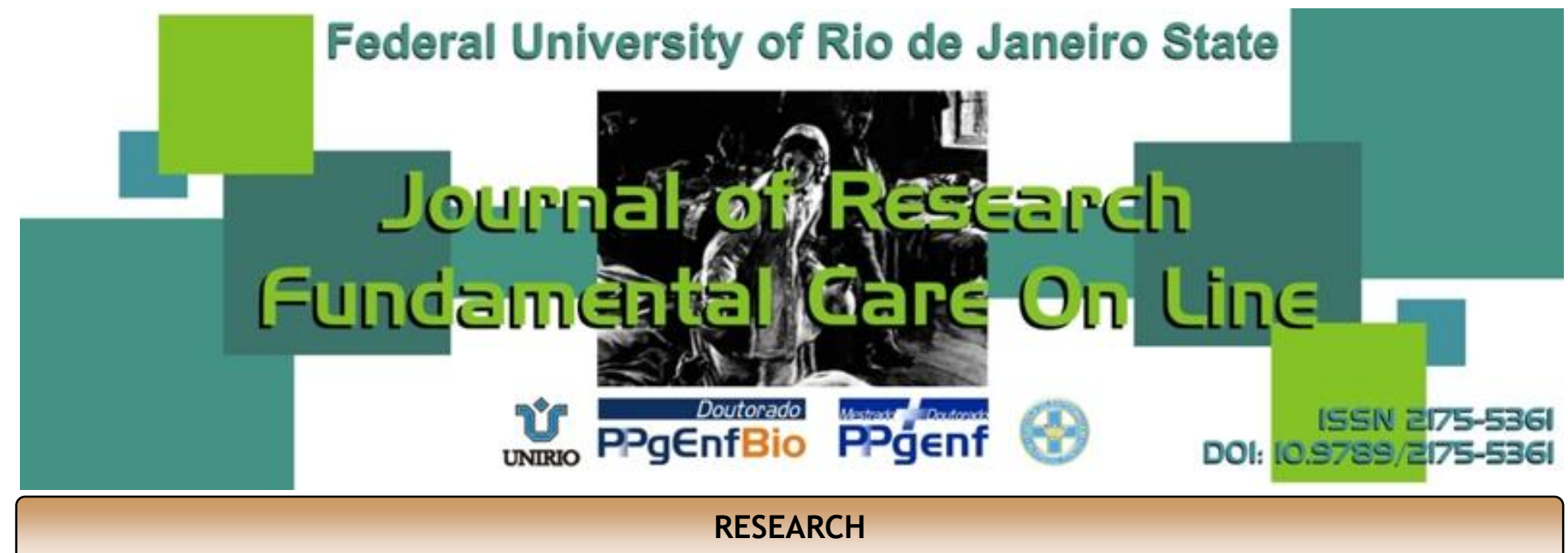

\title{
NURSE'S ACTION IN THE PAIN OF THE CARDIAC CLIENT: A STUDY FACE THE RECOGNITION OF THE NURSING INTERVENTION
}

ATUAÇÃO DA ENFERMEIRA NA DOR DO CLIENTE CARDIOLÓGICO: UM ESTUDO FRENTE O RECONHECIMENTO DAS INTERVENÇÕES DE ENFERMAGEM

ACTUACIÓN DE LA ENFERMERA DE LA ENFERMERA EN LA DOLOR DEL CLIENTE CARDIOLÓGICO: UN ESTUDIO FACE EL RECONOCIMIENTO DE LAS INTERVENCIONES DE ENFERMERÍA

Paula Vanessa Peclat Flores ${ }^{1}$, Natália da Palma Sobrinho ${ }^{2}$, Tais Verônica Cardoso Vernaglia ${ }^{3}$

\section{ABSTRACT}

Objectives: To identify acknowledgement of Acute Pain diagnosis, through its defining characteristics, by nurses in a coronary intensive care unit, correlate their interventions to the nomenclature established for Classification of suggested and optional Nursing Interventions. Method: Qualitative, descriptive study, realized with thirteen nurses from the Coronary Care Unit of a hospital in Rio de Janeiro. Results: of the eighteen defining characteristics described by NANDA, only seven of the nurses interviewed are recognized. Among twenty-seven possible interventions described in the Nursing Care Intervention (NIC), only seven are recognized, and, the majority ruled in the administration of analgesics, which affects nursing actions directed to the biomedical model. Conclusion: It is necessary that nurses reflect on the patient's individual needs, valorizing a care that involves a complex set of actions beyond biomedical care, ruled in comfort measures that promote the reduction of this symptom and consequently the improvement in the quality of care. Descriptors: Nursing, Nursing process, Pain, Cardiology.

\section{RESUMO}

Objetivos: Identificar o reconhecimento do diagnóstico de Dor Aguda, através das suas características definidoras, por parte dos enfermeiros em uma unidade intensiva coronariana; correlacionar suas intervençoes com a nomenclatura estabelecida para Classificação das Intervenções sugeridas e opcionais de Enfermagem. Método: Estudo descritivo, qualitativo, realizado com treze enfermeiros da Unidade Coronariana de um hospital no Rio de Janeiro. Resultados: Das dezoito características definidoras descritas por NANDA, sete são reconhecidas pelos enfermeiros entrevistados. Das vinte e sete possibilidades de intervenções descritas na Nursing Intervention Care (NIC), seis são reconhecidas, pautadas na administração de analgésicos, o que repercute em ações de enfermagem voltadas para o modelo biomédico. Conclusão: É preciso que o enfermeiro reflita sobre as necessidades individuais do cliente, valorizando um cuidado que envolva um complexo conjunto de ações além da atenção biomédica, pautadas em medidas de conforto que promovam a redução deste sintoma e consequentemente a melhoria na qualidade da assistência. Descritores: Enfermagem, Processos de enfermagem, Dor, Cardiologia.

\section{RESUMEN}

Objetivos: Identificar el reconocimiento del diagnóstico de Dolor Aguda, a través de sus características definidoras, por los enfermeros en una unidad intensiva de cuidados coronarios; correlacionar sus intervenciones con la nomenclatura establecida para Clasificación de las Intervenciones sugeridas y opcionales de Enfermería. Método: Estudio descriptivo, cualitativo, realizado con trece enfermeros de la Unidad de Cuidados Coronarios de un hospital en Río de Janeiro. Resultados: De las dieciocho características definidoras descriptas por NANDA, siete son reconocidos por los entrevistados. Entre los veintisiete posibles intervenciones descritas en la Nursing Intervention Care (NIC), seis son reconocidos, pautadas en la administración de analgésicos. Conclusión: Es necesario que el enfermero refleja sobre las necesidades únicas del cliente, valorando un cuidado que envuelva un conjunto compleja de acciones que además de la atención biomédica, pautadas en medidas de conforto que promueva la reducción de este síntoma y consecuentemente la mejoría en la calidad de la asistencia. Descriptores: Enfermería, Procesos de enfermería, Dolor, Cardiología.

${ }^{1}$ Federal Fluminense University. Assistant Professor II. Nursing Course. Interdisciplinary Departament at Rio das Ostras/ RIR. University of Rio das Ostras. Address: Rua Dr. Celestino n ${ }^{\circ}$ 74, Centro, Niterói. Rio de Janeiro. CEP 24020-091. E-mail: paulapeclat@enf.uff.br. ${ }^{2}$ Medical-Surgical Nursing Specialist/ Federal University of State of Rio de Janeiro UNIRIO. RN. Nacional Institute of Traumatology and Orthopedics of Rio de Janeiro. E-mail: natypsobrinho@hotmail.com. ${ }^{3}$ Assistant Professor II. MedicalSurgical Depatament. Alfredo Pinto Nursing School - Federal University of State of Rio de Janeiro UNIRIO. E-mail: taisvernaglia@gmail.com. 


\section{INTRODUCTION}

Critical patients may experience pain due to an underlying illness, an injury, a surgical process or a non-surgical intervention. Also, the pain may be the result of a variety of noxious stimuli present in the environment of a critical care unit (for example, an arterial catheter, central venous catheter, ventilatory support), or routine care in nursing. Although some patients may be able to communicate, verbally or not, their needs for pain control, others in serious condition, many times, may not do so in an appropriate manner, impairing their effective control. ${ }^{1}$

The nurse's performance in pain in hospitalized patients, especially in cardiac clients, requires a sensible perception. A study that evaluated the inter-relationship of pain in the postoperative period of myocardial revascularization, and the quality of life, have indicated that the patients who are able to verbalize their discomfort, refer to pain as a sensation of limiting their daily functions, delaying their recovery and considerably affecting their quality of life. ${ }^{2}$

Thus, the debates about the actions involved in the pain management are a reality in the care and research and its insertion in care logic. Thus, since January 2000, the Joint Commission on Accreditation of Healthcare Organizations (JCAHO) considers pain as fifth vital sign, which requires its evaluation and its registration, as well as other vital signs ${ }^{3}$.

It is an important vital sign, because in addition to the discomfort that it manifests, it also involves complex physiological reactions, such as autonomic and psychological manifestations leading to immunosuppression, decreased tissue perfusion, increased oxygen consumption and cardiac work, muscle spasm, altered respiratory mechanics and the release of hormones from the "stress", culminating in increased catabolism and change in the nitrogen balance. ${ }^{3-4}$

Thus, the pain, if not properly treated, is a potent stressor, triggering important physical or emotional responses, contributing to the worsening of the patient's prognosis. ${ }^{5-6}$

In addition to this, it is often the great prevalence of patients undergoing major surgeries that relate the intensity of pain ranging from moderate to intense. The example of pain expressed post-myocardial re-vascularization by sternotomy, a study conducted with patients who have been subjected to this type of surgery, showed that on a numerical scale from 0 (zero) to ten (ten), the intensity of pain reported ranged between 7 (seven) and 10 (ten). ${ }^{7}$

Therefore, the acute pain is an undeniable diagnosis. Recognizing this, the Association of North American Nursing Diagnoses (NANDA) through its diagnosis classification system proposes the diagnosis of acute pain defined as: unpleasant sensory and emotional experience that arises from tissue injury potential real or potential injury or described in such terms with sudden onset or slow, mild to severe, with early or predictable termination and duration of less than six months. ${ }^{5-8-9}$

Moreover, it is essential for the organization of nursing care to the patient with Acute Pain, through a systematic practice care. For such, it is essential that the use of the Nursing Process (NP) through the establishment of nursing diagnoses (ND), appropriate interventions and results.

The Nursing Intervention Classification (NIC) considers nursing intervention as "any treatment based on trial and clinical knowledge held by a nurse to improve the results of patient/client". In this context, the relation between ND and NIC, is the presentation of a

J. res.: fundam. care. online 2013. out./dez. 5(4):716-26 
Flores PVP, Sobrinho NP, Vernaglia TVC

standardized language for nursing, contributing to communication and documentation of practice. ${ }^{12-}$ 13

However, there are reports of consistent underestimation in the diagnosis and evaluation of pain, especially in intensive care environments, in which the difficulty or impossibility of the patient in expressing consciously the pain, make them even more difficult. ${ }^{5-6}$

In a study conducted in an intensive care unit, where 39 coronary patients were evaluated, it was conclusive that the pain was predominant and there was no correlation between pain and the presence of physiological changes evaluated, being the most frequent tachypnea (45.0\%) and increase in blood pressure(24.5\%). ${ }^{10}$

Thus, it being understood that the pain is a common finding in the coronary care unit due to the size of the complications of heart disease, and essential to the nursing team have knowledge about the set of actions needed to assist the patient with pain. For both, the nurse's decisionmaking must be guided in the identification of the nursing and diagnosis problem through the NANDA, establishing the expected results (NOC) and with this, identifying the path for nursing care so that cures, using nursing interventions (NIC) recommended. ${ }^{9-11-12-13}$

Based on this question, the object of this study is the nurses facing recognition about the Diagnosis "Acute Pain" and the respective nursing interventions for the client in a cardiac Intensive Care Unit.

With this, we ask ourselves how the nurse recognize the acute pain in a cardiac client and which their interventions in the face of this finding. The objectives were:

1. Identifying diagnostic recognition of Acute Pain through its defining characteristics, by nurses in a coronary intensive care unit;
Nurse's action in the pain of the...

2. Correlate the nurse's interventions in the patient's acute pain in the coronary care unit with the nomenclature for the classification of the suggested and optional Nursing interventions.

\section{METHODOLOGY}

This is a qualitative, descriptive and exploratory study ${ }^{14}$, on the basis of the narratives of thirteen Nurses from the coronary care unit of a in large military hospital located in Rio de Janeiro.

In this study, men and women aged over 18 years of age were included, acting as nurses (for at least the two previous months) in regime of daily work, 40 hours per week, or on duty day and night and that they were inserted in direct assistance to the patient in cardiology coronary care unit. All of the respondents read and signed, before inclusion in the study, an Informed Consent Form (ICF). This study was approved by the research ethics committee at the scenario of this study on the date 06/20/2011 whit the approval number is CAAE - 0022.0.313.221-11.

Through an established questionnaire with closed questions the subjects of the study were characterized. Three open-ended questions were made to deepen insufficiently addressed points in the closed questionnaire and which were relevant, responding to the object of study. They were: systematized way in which its activities to the patient with cardiac pain, as it identifies the pain in this public and when facing the identification of pain in patients; awake, sedated or prevented from verbalization/mobilization. All interviews were handwritten by the actual study subjects.

With this, the content of the information were grouped in the following analysis categories: The recognition of the defining characteristics of the nursing diagnosis and Characteristics of Acute Pain Nursing Interventions for Acute Pain according to the NIC. These were discussed in the

J. res.: fundam. care. online 2013. out./dez. 5(4):716-26 
Flores PVP, Sobrinho NP, Vernaglia TVC

light of bibliographic reference of "Acute Pain" according to the NANDA, inserted since $1996^{1}$ and nursing interventions (NIC) for this diagnosis. ${ }^{11-12}$

It is appropriate to clarify that there is no type-testing material, product or technique and there is no financial incentive for the participation of the subject selected for this research, in addition to guaranteeing the confidentiality of the information provided.

\section{RESULTS AND DISCUSSION}

The socio-demographic profile of 13 nurses, being $92 \%$ females and $8 \%$ males, revealed that $75 \%$ are between $26-28$ years of age, 58\% have 3 to 4 years of training, $67 \%$ day laborers and 33\% are full-time working in the sector between two months and 6 years. Of these, 83\% have postgraduate degrees, specializing in critical patient care and followed by surgical medicine. With regard to further training in the subject area object of this study: $75 \%$ Reported that they participate in refresher courses, through lectures and courses on pain. It is noteworthy that this figure probably includes the lecture conducted in this study unit, directed to update the physiology of pain assessment and pharmacologic therapy.

The recognition of defining characteristics of the nursing Acute Pain diagnosis:

The defining characteristics are the set of clinical findings that characterize the nursing diagnosis. In the acute pain diagnosis are evidenced as the following defining characteristics: Changes in Blood Pressure, Behavior of distraction (for ex: walking from one side to another, looking for other persons and/or activities, repeating activities), Protection Behavior, Expressive Behavior (e.g.: agitation,
Nurse's action in the pain of the...

moaning, crying, surveillance, irritability, sigh), Diaphoresis, Pupillary Dilation, Sleep Disorder, Evidence observed in Pain, Facial Expression (eyes dull appearance, appearance beat, movement fixed or dispersed, Facial Expressions), looking at them self, Narrowed Look(time perception changed, thought processes, suffer reduced interaction with people and the environment), protective gestures, changes in heart rate, changes in respiratory frequency, changes in appetite, position to prevent pain, Coded Report and verbal reports of pain. ${ }^{8}$

Therefore, through the implementation of the survey questionnaire it is impossible to observe the clinical manifestations recognized by interviewees for customer agreed, customer unable to verbalize/mobilize and sedated patient. The following table with the findings:

Table 1 - Recognition of the NANDA diagnosis defining characteristics - Coronary Care Unit, Military Hospital in Rio de Janeiro - 2011.

\begin{tabular}{|c|c|c|c|}
\hline \multirow[t]{2}{*}{ NANDA } & \multicolumn{3}{|c|}{ CLIENTE } \\
\hline & AWAKE & $\begin{array}{c}\text { WITHOUT } \\
\text { VERBALIZATIIN }\end{array}$ & SEDATED \\
\hline BLOLD PRESSLURE CHANGES & 2 & 6 & 6 \\
\hline $\begin{array}{l}\text { Expressive behavior } \\
\text { (agitation, moaning, сгуing, } \\
\text { irritability, staring and sigh) }\end{array}$ & 1 & 1 & 2 \\
\hline Facial Expression & 2 & 7 & 4 \\
\hline Changes in heart rate & 3 & 7 & 8 \\
\hline $\begin{array}{l}\text { Changes in respiratory } \\
\text { frequency }\end{array}$ & 3 & 6 & 7 \\
\hline Caded report & 3 & 3 & $-\overline{---}$ \\
\hline Verbal reports of pain & II & --- & ---- \\
\hline
\end{tabular}

Characteristics of nursing interventions for acute pain according to NIC:

The classification of nursing interventions (NIC) , has focused on the behavior of the nurse, the attitudes they take to help the patient to walk to the expected result (NOC). ${ }^{11}$

J. res.: fundam. care. online 2013. out./dez. 5(4):716-26 
To speak of the nursing diagnosis of acute pain, we realized that Jonhson ${ }^{11}$, relates three expected results: Pain Control, Comfort level and Level of pain. Each which presents interventions that often intertwine, being present in the three above described NOC's, an example is the application of heat/cold. Taking into account that the focus of this study and nurse's performance with to the patient pain hospitalized in a coronary care unit, we address the specific interventions for the outcome "pain level" since it is described the action most appropriate to this study. ${ }^{11}$

The interventions are classified as: main, suggested and optional as shown in the table below. In this case the main interventions are: Administration of analgesic, pain control and sedation control. These interventions have a closer relationship with the diagnosis and the result, but are best subdivided into suggested and optional Interventions, therefore, it was chosen to catalog the data in these last two categories, in order to better observe the collected data.

Tables 2 and 3 were adapted from the author quoted above, excluding interventions that do not fit the patients in question. In these tables are cataloged the behaviors executed by respondents when patients awake, unable to verbalize and/or mobilization and sedated. The items that were not cited by nurses were canceled out by solid lines.

Table 2 - Application of suggested nursing interventions for the NOC: pain level (Definition: Severity of pain reported or demonstrated) Coronary Care Unit, Military Hospital in Rio de Janeiro - 2011.

\begin{tabular}{|l|l|l|l|}
\hline \multicolumn{1}{|c|}{ NILs } & \multicolumn{3}{c|}{ Conditions of the patients } \\
\hline \multicolumn{1}{|c|}{ Suggested Interventions } & Awake & $\begin{array}{l}\text { Unable to } \\
\text { Verbalize }\end{array}$ & Sedated \\
\hline Acupressure & -- & -- & -- \\
\hline $\begin{array}{l}\text { Analgesic administration: intra- } \\
\text { spinal }\end{array}$ & -- & -- & -- \\
\hline Administration of anesthesia & -- & -- & -- \\
\hline
\end{tabular}

\begin{tabular}{|c|c|c|c|}
\hline $\begin{array}{l}\text { Medication Administration: EV, IM or } \\
\text { VQ }\end{array}$ & $\|$ & 10 & 10 \\
\hline Application of heat and cold & -- & -- & -- \\
\hline Drug Cantrol & 1 & -- & -- \\
\hline Enviranment Contral: camfart & 2 & 1 & \\
\hline Skin Stimulation & -- & -- & -- \\
\hline $\begin{array}{l}\text { Transcutaneous electrical } \\
\text { stimulation of the nerve (TENS) }\end{array}$ & -- & -- & -- \\
\hline Guidance for image focusing & -- & -- & -- \\
\hline Immobilization & -- & -- & -- \\
\hline Positioning & 2 & 2 & \\
\hline Prescription of medicines & -- & -- & -- \\
\hline Reduction of anxiety & -- & -- & -- \\
\hline Reduction of flatulence & -- & -- & -- \\
\hline Supervision & 4 & -- & -- \\
\hline
\end{tabular}

Table 3 - Classification of nursing interventions optional for NOC: pain level (definition: severity of pain reported or demonstrated) - Coronary Care Unit, Military Hospital in Rio de Janeiro - 2011.

\begin{tabular}{|c|l|l|l|}
\hline NILs & \multicolumn{3}{|c|}{ Conditions of the patients } \\
\hline Optional Interventions & Awake & $\begin{array}{l}\text { Unable to } \\
\text { Verbalize }\end{array}$ & Sedated \\
\hline Biofeedback & -- & -- & -- \\
\hline Distraction & -- & -- & -- \\
\hline Hypnosis & -- & -- & -- \\
\hline Simple Massage & -- & -- & -- \\
\hline Monitoring of vital signs & 2 & 1 & 2 \\
\hline Music Therapy & -- & -- & -- \\
\hline Presence & -- & -- & -- \\
\hline Pragressive Muscle Relaxation & -- & -- & -- \\
\hline Simple relaxation therapy & -- & -- & -- \\
\hline Touch & -- & -- & -- \\
\hline Therapeutic Touch & -- & -- & -- \\
\hline
\end{tabular}

From the presentation of the data, it is possible to make the correspondence between the nursing interventions for pain through the result of pain level with the nursing interventions provided in the study scenario.

In recent decades, the application of the Nursing Process through the SNC has given autonomy and scientificity to nursing actions. The methodology used by this process contributes

J. res.: fundam. care. online 2013. out. / dez. 5(4):716-26 
Flores PVP, Sobrinho NP, Vernaglia TVC

to the early identification and treatment of nursing problems. ${ }^{15}$

Through its stages, the SNC gives greater security for patients, since, to be implemented, requires in each of these stages, the correct clinical judgment on the part of the nurse. This is a tool that promotes the improvement of nursing practice based on knowledge, in thought and in clinical decision-making with the support of scientific evidence, obtained from the evaluation of subjective and objective data of the individual.

When we talk about the defining characteristics of the nursing diagnosis of acute pain ahead healthcare practice (Table 1), it can be seen that the eighteen defining characteristics described by NANDA, only seven are recognized by nurses interviewed. The defining characteristics: behavior of distraction, behavior of protection, diaphoresis, pupillary dilation, sleep disorder, evidence observed in pain, focus on yourself, focus narrowed protectors, gestures, change in appetite and position to prevent pain were not cited by the research subjects.

In the patient category, awakened the cited defining characteristic was a verbal report followed by changes in heart rate and breathing. For patients unable to verbalize and/or mobilize, facial expression followed by changes in blood pressure, respiratory and heart were recognized as signal for pain. For sedated patients, the cardiac, respiratory, and blood pressure were prevalent.

These findings direct to a nursing care focused primarily for interpretation of hemodynamic events (change of blood pressure, respiratory and cardiac) regardless of the patient assisted, where nurses are based to perform their daily activities in the technical model, ie, facing procedures and assistive technologies that disregards individual and emotional aspects of the patient.
Nurse's action in the pain of the...

It was observed that defining characteristics such as: gestures, focus narrowed protectors (time perception changed, reduced interaction with environment and people) and even position avoid pain that are aspects that become evident only through individualized assessment were not referred to by the subject of the research, which reinforces the line of the biomedical model in nursing care.

Thus, the defining characteristics recognized by nurses working in the coronary care unit direct to actions based on hemodynamic changes. Stressing that the biomedical model is still present in our care reality which makes the nursing care limited. This perspective shows that in spite of legal autonomy for application of SNC the practice of systematic actions is still under construction in care units. ${ }^{16}$

In relation to the characteristics of the nursing interventions for pain second NIC (Table 2 ), in the category agreed and unable to mobilization and/or verbalization the interventions presented by the subjects of the study were similar, the intervention that were most described by nurses and administration of analgesics or medicines, some professionals have added that patients with pain after some time return for reassessment, which represents the suggested intervention "supervision" which is defined as: Acquisition, interpretation and purposeful synthesis and continuous patient data aiming at clinical decision making. ${ }^{17-18}$

Professionals described it as care the categories awake, unable to verbalize and / or immobilize and sedated concern for lighting and noise that can interfere with pain intensity, this falls under the suggested intervention control environment: comfort.

The deliberate positioning of the patient or part of their body to promote physiological and/or psychological well-being, can decrease the pain

J. res.: fundam. care. online 2013. out./dez. 5(4):716-26 
Flores PVP, Sobrinho NP, Vernaglia TVC

reported and this intervention was described in the unit for patients; awake, immobilized and sedated. ${ }^{16}$

When speaking of patient care with pain, one should take into consideration the nurseclient interaction is required in addition to technical skills, observation and communication with the patient, therefore, the nurses reported that they converse and evaluate the psychological aspects which may influence the pain. The intervention suggested by NIC emotional support corresponds with such care, however, this intervention suggested is inserted only in the NOC comfort level.

For the evaluation of nursing care to the client with pain it is necessary for observation of patient behavioral reactions such as: how to express their grief and express pain, talking, crying, non-verbal communication for this condition can influence the decision making of nurses for the choices of pharmacological therapies and / or emotional support.

The interventions suggested Application of heat/cold, Immobilization, reduction of anxiety, reduction of flatulence were not described as care for pain control despite being applied interventions in the healthcare practice.

Music therapy was not mentioned by the interviewees, even being a simple and effective practice, as other studies in the area. The noise effect in a hospital environment usually causes fear and stress, intensifying painful conditions. The control of environmental noise through pleasant music at appropriate volumes, reduce the heart rate, blood pressure and facilitating levels of relaxation, which in turn favors the control of pain levels. ${ }^{17}$

Regarding sedated patients the intervention was proposed that more nurses are administering analgesics or drugs, this is an intervention suggested by NIC. The optional J. res.: fundam. care. online 2013. out./dez. 5(4):716-26
Nurse's action in the pain of the...

intervention monitoring of vital signs was reported as a sign of the emergence and control of pain intensity.

The physiological factors associated with pain is manifested as tachycardia, increased blood pressure, tachypnea, pallor, sweating or muscle tension. Hemodynamic monitoring mainly from patient use of sedative drugs is an effective marker of (re) assessment of pain. ${ }^{6}$

The interventions presented are based on an international publication that has been adapted for application to the national reality through the process of content validation, which constitutes an important tool in refining nursing classifications. The Interventions - Acupressure, Administration of analgesics: Intra spinal, administration of anesthesia, transcutaneous electric stimulation of the nerve (TENS), skin stimulation, biofeedback and hypnosis were not recognized by the subjects as they do not present the reality nursing care in Brazil. ${ }^{19}$

In the analysis of the interventions made in the data collection instrument it was possible to see that there is a correspondence between the interventions proposed and implemented by NIC in the healthcare practice.

\section{CONCLUSION}

It was possible to discuss the object of this study through the NANDA and NIC bibliographic references. We noticed that the difficulties of classification begins at the moment that the nurse needs to understand the physiology of pain, thereby making it impossible to think of the most appropriate evaluation methods and subsequently the correct decisions.

The literature presents a wide discussion on the physiology of pain, evaluation methods for each patient and countless pharmacological and non-pharmacological therapies. However, the nursing care to patients with pain requires 
Flores PVP, Sobrinho NP, Vernaglia TVC

professional clinical reasoning, observation of the psychological aspects and establishment of patient $x$ nurse communication.

We identified that among the interventions suggested indicated by NIC, only five are reported in the daily practice of th interviewed nurses: Medication Administration: IV, IM or VO, drug control, control of the environment: comfort, positioning, supervision. Of the six non-cited interventions, the ones which call more attention are: Application of heat and cold, Guidance for focusing the image, reduction of anxiety and reduction of flatulence.

Already in optional interventions, indicated by NIC, only one of the eleven found in the literature, was reported, the Monitoring of Vital Signs. Interventions such as touch, music therapy, relaxation therapy, simple presence and massage simple were not mentioned. We realized in daily care practice that these interventions are implemented by many nurses, but probably are not recognized as part of their scientific care.

There were no significant differences regarding the nursing conducts for awaken coronary patients, unable to verbalize and/or mobilize as well as sedated. Interventions for these groups are restricted to the administration of analgesics (11 for awakened patients, 10 for patients who don't verbalize and 10 for sedated), by configuring also the strong influence and the predominance of a biologistic care model, which prioritizes the disease. Although this practice is important, does not include other individual needs, where the techniques are complementary to care.

The relationship of nursing interventions regarding pain are diverse, but their implementation is very small, only six of what is possible. The implementation of systematized nursing actions, from established diagnoses and J. res.: fundam. care. online 2013. out./dez. 5(4):716-26
Nurse's action in the pain of the...

interventions guidelines, and the path for the legalization of so many other actions that are necessary in health care. Therefore not incur the risk of transfer to the foreign scientific knowledge domain that our profession gives us.

The nurse's role in the daily care is replete with interventions that are often not recognized as systematic care, therefore, are often not even reported. An example is the optional intervention "presence", we perform every day but not always recognized the potential that it has on relieving pain. For this reason, it is essential to use instruments that guide the nurse's action, indicating the main and suggested interventions in daily activities.

The use of the international classification of nursing interventions (NIC), from the time of diagnosis of NANDA "acute pain" provides autonomy for nurses in decision-making. However, despite decades of discussion on the professional autonomy of nurses, we still need to advance in challenges to ensure the implementation of the process and the systematization of nursing care in different forms of suffering and illness of the population.

In this aspect, the universities play a fundamental role in this way already that provides the first contact with the nursing theories, demonstrate their applicability and guarantee a space for discussion on the challenges of this practice in clinical, academic and institutional spaces.

Therefore the commitment should be kept in order to prepare future nursing professionals in a scientific, organized and systematized approach. We must overcome the academic obstacles, such as non-use of teaching methodologies, healthcare, and the lack of teacher preparation, who have not acquired in their training process, skills and 
Flores PVP, Sobrinho NP, Vernaglia TVC

competencies for the use of the Nursing Process as a healthcare tool.

With the publication of Resolution COFEN No. 272/2002 which provides for the systematization of nursing care in the Brazilian health institutions, ${ }^{14}$ the adoption of SNC has demanded training both for the nurses who graduated before this year, as well as for those who graduated after this date, since some higher education institutions are still in the process of curricular adequacy.

This is not to delegate the responsibility for educational institutions (universities and continuing education), strategies for the successful implementation of SNC transcending theoretical questions. The application of the nursing process has as a starting point for continuous training has been related to the people involved in the work process. This fact takes into account the nurses' involvement for the systematization of nursing care is in addition to institutional rules, the socialization of knowledge, the professional involvement and the commitment of the leadership and care team is essential for the SNC occur in a systematic way and individualized as the theoretical assumptions.

Before so many discussions on the implementation of the nursing care system it is believed that the standardization of language through this methodology of work can benefit not only the customer with pain, but to ensure the safety of all customer care.

\section{REFERENCES}

1. Tietize, KJ. Pain control in the critically ill adult patient. Uptodate [Internet]. $2013 \mathrm{apr}$ [acesso em 2013 maio 31]. Disponível em: http: / / uptodate.com/contents/pain-control-inthe-crtically-ill-adult-patientssource-
Nurse's action in the pain of the...

search_resultssearch-pain-

managerselecttitle3 150.

2. Fonseca, G., Parcianello, M., Zamberlan, C., Marinho, RM., Carmo, PD, Siqueira, HH. Dor no pós-operatório de revascularização do miocárdio e sua interrelação com a qualidade de vida. Revista de pesquisa: cuidado é fundamental online [Internet]. 2013 mai [acesso em 2013 maio 30]; 5(2):3636-44. Disponível em: http: / / www.seer.unirio.br/index.php/cuidadof undamental/article/view/2108/pdf_745

3. Bagatini A, Fuhrmeister A, Fortis EF. Anestesia: a vitória sobre a dor. Porto Alegre: SARGS, 2001.

4. Pimenta C, Cruz D. Instrumentos para avaliação da dor: o que há de novo em nosso meio. Arq Bras Neurocir 1998 Mar 1; 17(1):1524.

5. Aquino RD, Fonseca $\mathrm{SM}$, Lourenço EPL, Leite AL, Bettencourt ARC. Mapeamento dos diagnósticos de enfermagem em uma unidade de pneumologia. Acta Paul Enferm [Internet]. 2011 maio [acesso em 2012 nov 01]; 24(2):1928. Disponível em: http: / / www.scielo.br/pdf/ape/v24n2/06.pdf

6. Miranda AFA. Avaliação da intensidade de dor e sinais vitais no pós-operatório de cirurgia cardíaca. Rev Esc Enferm USP [Internet]. 2011 abril [acesso em 2012 nov 01]; 45(2): 327-33. Disponível

em: http: //www.scielo.br/pdf/reeusp/v45n2/v45n2 a03.pdf http:

7. Lima LR, Stival, M, Barbosa M, Pereira L. Controle da dor no pós operatório de cirurgia cárdica: uma breve revisão. Rev Eletr de Enf [Internet]. 2008 maio [acesso em 2012 nov 01];10(2):521-9. Disponível em: 
Flores PVP, Sobrinho NP, Vernaglia TVC

http: //www.fen.ufg.br/revista/v10/n2/v10n2a2 3.htm

8. North American Nursing Diagnosis Association. Diagnóstico de enfermagem da Nanda: definições e classificações 2012-2014. Porto Alegre: Artmed; 2012.

9. Barros, AL. Classificações de diagnósticos e intervenções de enfermagem: NANDA-NIC. Acta Paul Enferm [Internet]. 2009 Especial 1 [acesso em 2013 maio 30]; 22(Especial 170 anos):864-7. Disponível em: http://www.scielo.br/pdf/ape/v22nspe/03.pdf 10. Andrade, EV; Barbosa, MH; Barichello, E. Avaliação da dor em pós-operatório de cirurgia cardíaca. Acta paul. enferm. [Internet]. 2010 mar [acesso em 2013 maio 30]; 23(2): 224-29. Disponível

em: http: / / www.scielo.br/pdf/ape/v23n2/12.pdf.

11. Johnson $M$, Buleccheck $G$, Butchert $H$, et al. Ligações entre NANDA, NOC E NIC, $2^{a}$ ed. Porto Alegre: Artmed, 2009.

12. Bulechek, GM; Butcher, HK; Douchterman, JM. NIC: Classificações de Enfermagem. 5 ${ }^{a}$ Ed. Riod e Janeiro: Elesevier, 2010.

13. Lucena, AF; Gutiérrez. MG; Echer, IC; Barros, AL. Intervenções de Enfermagem utilizadas na prática clínica de uma Unidade de Terapia Intensiva. Ver. Latino. Am. [Internet]. 2010 set [acesso em 2013 maio 31];18(5):1-9. Disponível:

http://www.scielo.br/pdf/rlae/v18n5/pt_06.pd f

14. Polit DF, Hungler BP. Fundamentos de pesquisa em enfermagem. $3^{a}$ ed. Porto Alegre: Artes Médicas, 1995.
Nurse's action in the pain of the...

15. Silva MM. A Sistematização da assistência de enfermagem em cuidados paliativos em oncologia: visão dos enfermeiros. Acta Paul Enferm [Internet]. 2011 março [acesso em 2012 nov 01];24(2):172-8. Disponível: http: / / www.scielo.br/pdf/ape/v24n2/03.pdf

16. Silva EGC, Oliveira VC, Neves GBC, Guimarães TMRO. Conhecimento do enfermeiro sobre a sistematização da assistência de Enfermagem: da teoria a prática. Rev Esc Enferm USP [Internet]. 2011 nov [acesso em 2012 nov 01]; 45(6):1380-6. Disponível em: http: //www.scielo.br/pdf/reeusp/v45n6/v45n6 a15.pdf

17. Secoli SR. Dor pós-operatória: combinações analgésicas e eventos adversos. Rev Esc Enferm USP [Internet]. 2009 dez [acesso em 2012 nov 01]; 43(Esp 2): 1244-9. Disponível em:

http: / /www.scielo.br/pdf/reeusp/v43nspe2/a1 7v43s2.pdf

18. Valen R, Vuuren H, Domburg R, Domburg R, Woerd D, Hofland J, et al. Pain management after cardiac surgery: experience with a nursedriven pain protocol. Eur J Cardiovasc Nurs 2012 january $1 ; 11(1)$ : 62-9.

19. Monteiro, DR; Pedroso, ML; Lucena, AF; Almeida, MA; Mottas, MG. Estudos sobre validação de conteúdo em interface com os sistemas de classificação de enfermagem: revisão de literatura. Rev enferm UFPE [Internet]. 2013 maio [acesso em 2013 maio 31]; 7 (esp):4130-7. Disponível em:ww.revista.ufpe.br/revistaenfermagem/ind ex.php/revista/article/630 
Elaborated from the Graduate Course Monograph on Level of Specialization, in the form of InService Training for Nurses, in the Form of Residency. Title: The nurse's actions towards the patient's pain in the coronary care unit: A study about the systematization of nursing care. December/2011.

Received on: 01/11/2012

Reviews required: 23/05/2013

Approved on: 07/06/2013

Published on: 01/10/2013

J. res.: fundam. care. online 2013. out./dez. 5(4):716-26 